\title{
IMPLEMENTASI PEMBELAJARAN KIMIA BERBASIS DARING (GOOGLE CLASSROOM DAN ZOOM CLOUD MEETING) DI SMK NEGERI 1 TANJUNG PALAS
}

\author{
MIA INDAH PERMATASARI \\ SMK Negeri 1 Tanjung Palas \\ e-mail: mianiezzz@gmail.com.id
}

\begin{abstract}
ABSTRAK
Penelitian ini bertujuan untuk mendeskripsikan pelaksanaan pembelajaran Kimia berbasis daring di SMK Negeri 1 Tanjung Palas.Sebagai media penunjang pembelajaran daring menggunakan beberapa platform online seperti Google Classroom sebagai media interaksi kelas virtual berbasis web, dan menggunakan Zoom Cloud Meeting sebagai media live streaming. Peneliti menggunakan metode penelitian kualitatif deskriptif sehingga pemanfaatan kedua platform digital tersebut dapat diteliti lebih rinci mulai dari kelemahan hingga kelebihannya masing-masing. Sebagai hasil penelitian menunjukkan bahwa pembelajaran daring telah dilaksanakan dengan baik, dan memanfaatkan berbagai media pembelajaran sehingga pembelajaran Kimia menjadi lebih bervariatif.Kimia yang selama ini dianggap menakutkan, jadi pelajaran yang menyenangkan bagi siswa.Adapun kendala yang dihadapi adalah beberapa siswa tidak memiliki HP, tidak terjangkaunya Signal, keterbatasan dana untuk membeli paket data Internet, serta kurangnya koordinasi antara guru dan siswa.
\end{abstract}

Kata Kunci: pembelajaran daring, pembelajaran kimia,google classroom, zoom cloud meeting

\section{PENDAHULUAN}

Saat ini, dimana masyarakat dunia sedang dilanda virus covid-19, tidak terkecuali Indonesia.Hampir seluruh negara mengalami dampak wabah ini, hingga banyak negara-negara yang menetapkan status lockdown dan antisipasi lainnya guna memutuskan mata rantai penyebaran COVID-19. Akibat dari kebijakan tersebut banyak sektor yang lumpuh, misalnya sektor ekonomi yang paling utama lumpuh akibat pandemi ini. Selain sektor ekonomi yang mengalami dampak, pendidikan juga merupakan salah satu sektor yang juga mengalami langsung dampak pandemi ini. Menurut UNESCO tercatat setidaknya 1,5 milyar anak usia sekolah yang terkena dampak COVID-19 dari 188 negara termasuk 60 juta diantaranya ada di negara Indonesia (https://kependudukan.lipi.go.id). Akibat pandemi ini sekolah-sekolah ditutup, hal ini dilakukan dengan tujuan untuk mencegah penyebaran COVID-19. Merujuk pada fenomena penyebaran Covid-19 yang kian masif,Dunia pendidikan mengalami perubahan sangat drastis, proses pembelajaran mengalami revolusi, yang semula dilakukan pmbelajaran tatap muka menjadi pembelajaran jarak jauh. Hal ini memberikan ketakutan tersendiri bagi siswa dalam proses pembelajaran. Ketakutan ini mulai dari ketakutan atas pengekangan aktivitas, ketakutan akan kegagalan belajar, dan ketakutan akan kehilangan hubungan sosial. Maka dari itu akademisi perlu mengadopsi atau memilih teknologi yang efektif dalam proses pembelajaran (Al-Maroof, R. S., et al., 2020).

Semua sekolah di Indonesia terdampak, tak terkecuali dengan SMK Negeri 1 Tanjung Palas, dunia pendidikan menuntut untuk tetap dapat menyelenggarakan pendidikan bagi peserta didik walau dengan Pembelajaran Jarak Jauh, sebagaimana tercantum dalam Surat Edaran Mendikbud Nomor 4 Tahun 2020 Tentang Pelaksanaan Kebijakan Pendidikan dalam Masa Darurat Penyebaran Covid-19 bahwa proses Belajar dari Rumah (BDR) melalui Pembelajaran Daring/ Jarak Jauh (PJJ) dilaksanakan untuk memberikan pengalaman belajar yang bermakna bagi siswa, tanpa terbebani tuntutan menuntaskan seluruh capaian kurikulum untuk kenaikan kelas maupun kelulusan.Oleh karena itu , sekolah memerlukan media sebagai sarana untuk pembelajaran jarak jauh atau secara online. berbagai Platfrom yang bisa digunakan sebagai media pembelajaran oleh sekolah.Di antaranya Google Classroom, Zoom Meeting,dan sebagainya. 
Google classroom yaitu aplikasi yang menggunakan jaringan internet dengan menggunakan computer dan/atau handphone (Hakim, 2016). Google classroom dapat mengaktifkan siswa pada proses pembelajaran disebabkan media ini dapat menampilkan teks, gambar, dan video pada saat proses pembelajaran berlangsung. Selain itu, aplikasi ini dapat 1) menyederhanakan kegiatan membuat, mendistribusikan, dan menilai tugas siswa tanpa harus bertatap muka langsung (Mahayoni, 2020; Okmawati, 2020); 2) melakukan percakapan tentang tugas dan guru dapat mengetahui kemajuan siswa (Beal, 2020); 3) menjadi media interaksi antara guru dengan siswanya atau siswa dengan siswa lainnya (Liu \& Chuang, 2016); dan 4) menampung dan mengatur waktu pengumpulan tugas oleh guru yang akan menumbuhkan rasa kedisiplinan dan tanggung jawab bagi siswa dalam mengerjakan tugas(Kusuma dewi,dkk, 2021)

Selanjutnya Zoom Cloud Meeting, merupakan sebuah media pembelajaran menggunakan video. Pendiri aplikasi Zoom Meeting yaitu Eric Yuan yang diresmikan tahun 2011 yang kantor pusatnya berada di San Jose, California. Aplikasi ini tidak hanya digunakan untuk pembelajaran saja tetapi bisa digunakan untuk urusan perkantoran maupun urusan lainnya. Dalam aplikasi Zoom Cloud Meeting ini kita bisa berkomunikasi langsung dengan siapapun lewat video. Oleh karena itu, memang cocok digunakan sebagai media pembelajaran.

Penelitian ini bertujuan untuk mengetahui seberapa besar pemanfaatan Google Classroom dan Zoom Cloud Meeting sebagai media pembelajaran di masa social distancing terhadap siswa SMK Negeri 1 Tanjung Palas dalam pembelajaran Kimia.

\section{METODE PENELITIAN}

Jenis penelitian ini menggunakan metode kualitatif deskriptif. Metode yang digunakan tersebut untuk menemukan metode yang tepat sehingga dapat diimplementasikan pada proses pembelajaran secara luas (Arifin, 2013; Sugiyono, 2011). Metode pembelajaran ini memanfaatkan aplikasi google classroom dan Zoom Cloud Meeting, yang dapat dijadikan alternatif pembelajaran oleh guru dalam proses pembelajaran daring. Subjek penelitian ini yaitu siswa kelas X APHPI di SMK Negeri 1 Tanjung Palas.Penelitian ini melibatkan 19 siswa kelas $\mathrm{X}$ APHPI. Materi yang digunakan yaitu Struktur Atom.

Teknik pengumpulan data dalam penelitian ini yaitu teknik dokumentasi dan observasi. Teknik analisis yang digunakan yaitu analisis induktif. Setelah data terkumpul, oleh peneliti akan dianalisis dan diinterpretasikan sehingga akan mudah dalam menarik kesimpulan akhir. Analisis data secara induktif yaitu segala hal yang bersifat khusus akan dicari dan ditarik kesimpulannya untuk dapat menjelaskan segala hal yang bersifat umum (Naserly, 2020). Segala hal yang ditemukan oleh peneliti akan dianalisis dan diobservasi melalui data dan berbagai studi kepustakaan. Hal ini untuk mencapai keberhasilan dalam penggunaan metode deskriptif melalui observasi sehingga terfokus pada tujuan penelitian.

Pada penelitian ini menggunakan beberapa tahap yakni tahap studi pendahuluan dengan mencari sumber yang menjelaskan penggunaan google classroom, dan zoom cloud meeting. Tahap kegiatan penelitian melibatkan siswa untuk menggunakan metode pembelajaran daring. Selanjutnya pada tahap evaluasi yaitu dilakukan setelah pembelajaran menggunakan google classroom dan zoom meeting.Peneliti berharap dapat memberikan data tentang manfaat metode pembelajaran alternatif yang diterapkan selama proses pembelajaran Kimia secara daring.

\section{HASIL DAN PEMBAHASAN}

HASIL

Penggunaan mobile learning dalam kegiatan belajar mengajar memiliki dampak yang sangat positif bagi siswa yakni siswa dapat memanfaatkan waktu belajarnya dengan lebih fleksibel. Dengan demikian, terdapat peluang yang tinggi untuk meningkatkan hasil belajar siswa (Efendi \& Marpaung, 2018). Dalam penelitian ini platform yang digunakan untuk menunjang pembelajaran berbasis mobile learning adalah Google Classroom dan Zoom Cloud Meeting. Kedua platform tersebut mudah untuk diaplikasi oleh guru dan siswa. Siswa sebagai 
generasi $\mathrm{Z}$ yang berada di era pembelajaran abad 21 sudah seharusnya untuk diberikan pengalaman belajar yang lebih menarik, menyenangkan, dan fleksibel dengan memanfaatkan teknologi yang sedang berkembang.

\section{Implementasi Google Classroom}

Google Classroom (GCR) merupakan platform berbasis internet yang disediakan oleh google sebagai sistem manajemen pembelajaran yang bertujuan untuk memudahkan penyusunan, penyebaran, dan penilaian tugas secara online (Wicaksono, 2020; Qomariah, 2019). Dengan menggunakan google classroom guru dapat memberikan pengumuman, tugas, Jurnal materi pembelajaran, mengabsen siswa, serta mengetahui siapa saja yang telah dan yang belum mengumpulkan tugas, sedangkan siswa dapat mengumpulkan tugas serta mengakses materi yang telah diberikan guru kapanpun dan dimanapun.

Hal tersebut sesuai dengan pernyataan Ali (2020) dimana google classroom dapat membangun suasana belajar yang lebih produktif dan bermakna bagi siswa dengan menyederhanakan tugas, meningkatkan kerjasama, serta membina komunikasi, tidak hanya itu dengan google classroom guru dapat membuat kelas, memberikan tugas, memberikan penilaian pada satu tempat. Gambar 1 adalah contoh penggunaan google classroom dalam pembelajaran daring.

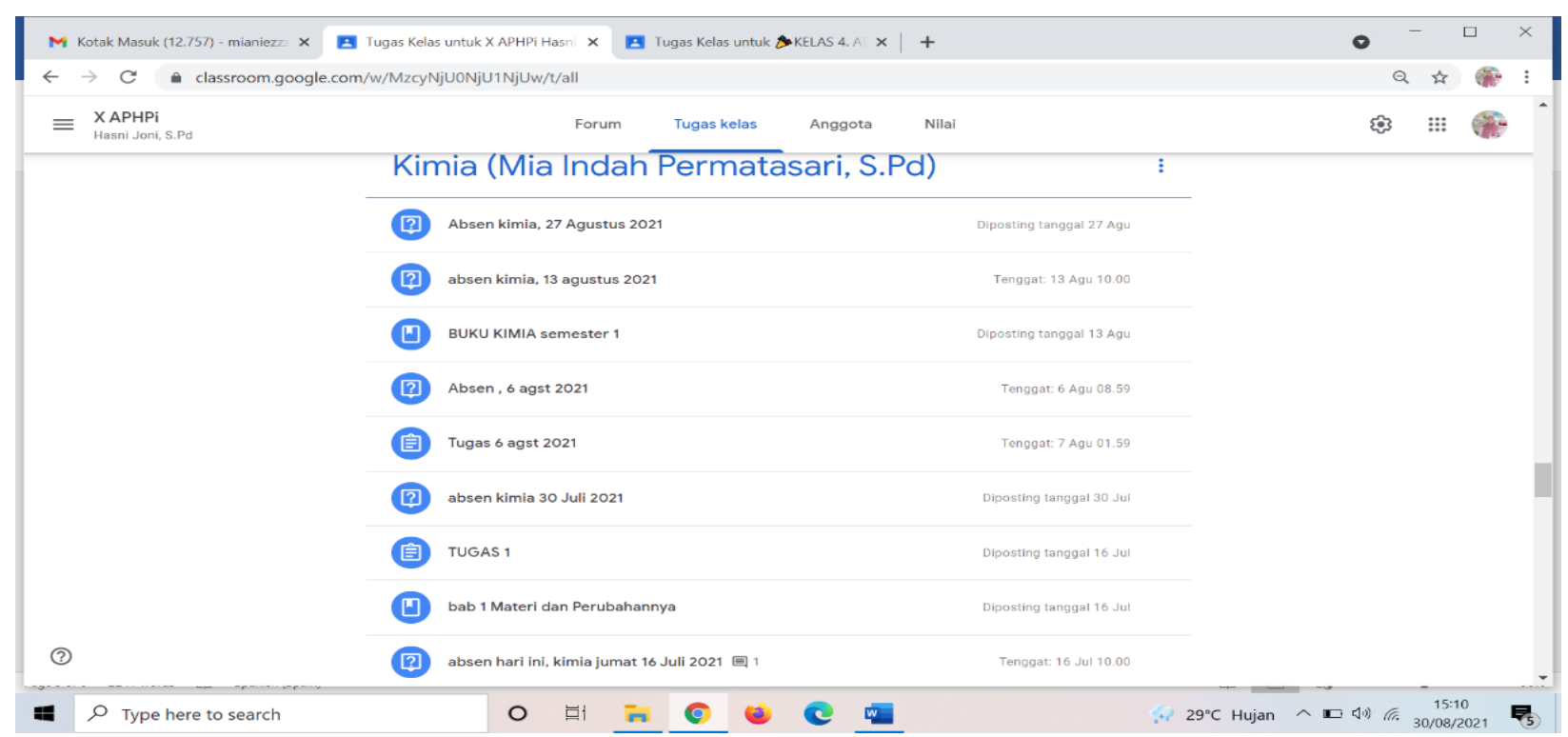

Gambar 1. Tampilan Google Classroom pada kelas X APHPI pembelajaran kimia (Sumber: Dokumen pribadi)

Google Classroom terhubung dengan semua layanan Google for Education lainnya, salah satunya adalah Google Calendar. Pemanfaatan Google Calendar sebagai pengingat tenggat waktu pengumpulan tugas oleh siswa di Google Classroom dapat meningkatkan kedisiplinan siswa. Hal tersebut dikarenakan siswa akan mengetahui kapan deadline dari tugas mereka, sehingga mereka dengan mudah dapat mengumpulkan tugas secara tepat waktu. Hal tersebut sesuai dengan penelitian Prada (2017) dimana ia menyatakan bahwa dengan memanfaatkan Google Calendar maka tidak terdapat alasan lagi bagi siswa untuk lupa atau bahkan terlambat mengumpulkan tugas. Selain terkait pengumpulan tugas, guru juga dapat menyimpan file perangkat pembelajaran seperti modul, powerpoint, dan file lainnya yang akan digunakan dalam proses pembelajaran.

Penggunaan Google Classroom dalam kegiatan pembelajaran online di SMK Negeri 1 Tanjung Palas dilakukan dengan cara guru membuat room google classroom untuk siswa dan guru. Selanjutnya siswa bergabung di room yang sudah disediakan dengan memasukkan kode kelas terlebih dahulu. Kemudian guru dapat memanfaatkan google classroom untuk mendistribusikan materi atau tugas dengan cara memposting file- file materi atau tugas di google classroom, sehingga dapat diakses secara langsung oleh seluruh siswa yang sudah 
bergabung di dalamnya. Untuk penilaian guru dapat langsung menilai hasil kerja siswa, selain itu dengan menggunakan google classroom guru dapat mengetahui jumlah siswa yang sudah dan siswa yang belum mengumpulkan tugas. Hal tersebut sesuai dengan pernyataan Aryani (2020) dimana, dengan menggunakan google classroom guru akan lebih mudah dalam melakukan evaluasi terhadap proses belajar siswa. Dengan adanya layanan google classroom yang cukup lengkap maka pembelajaran secara daring dapat dilaksanakan dengan efektif dan efisien.

Pemanfaatan google classroom dalam kegiatan belajar dan mengajar di SMK Negeri 1 Tanjung Palas tidak selalu berjalan dengan lancar. Sebab dalam praktiknya, masih terdapat siswa yang tidak dapat hadir untuk mengikuti pembelajaran. Ketidakhadiran siswa sebagian besar diakibatkan oleh tidak adanya jaringan internet yang memadai untuk mengakses google classroom. Wicaksono (2020), dalam penelitiannya juga menyatakan bahwa kenyataan di lapangan kendala dalam pemanfaatan google classroom adalah jaringan internet yang belum bisa diakses siswa secara keseluruhan. Selain itu, masih ada juga siswa yang gaptek, tidak bisa menggunakan Google Classroom, dan mereka tidak mau berusaha untuk belajar.

\section{Implementasi Zoom Cloud Meeting}

Zoom Cloud Meeting adalah salah satu aplikasi yang menyediakan fasilitas interaksi tatap muka pendidik dan peserta didik secara virtual melalui video conference. Aplikasi ini merupakan aplikasi yang digunakan sebagai media komunikai jarak jauh dengan menggabungkan konferensi video, obrolan, pertemuan online dan kolaborasi seluler. Penggunaan meeting dalam aplikasi ini bisa menampung 1000 peserta bersama dalam satu pertemuan secara virtual.Fitur yang ada antara lain panggilan telephone, webinar, presentasi, dan masih banyak lainnya. Keberlangsungan video konferensi pada saat meeting keamanan rekamannya lebih terjaga (Brahma, 2020). Zoom cloud Meeting merupakan sebuah layanan konferensi video yang memiliki kemampuan praktis dalam menghadirkan suasana meeting secara daring. Seperti yang dilansir id.cloudhost.com, pengguna aktif Zoom kian melonjak pesat sekitar 2,22 juta perbulan sejak pandemi COVID-19 merebak secara global per Maret 2020 lalu. Aplikasi berbayar ini dapat diakses secara cuma-Cuma dengan kapasitas pengguna maksimal 100 orang dan batasan durasi konferensi sekitar 40 menit.

Dalam pengajaran daring,banyak kemudahan saat menggunakan Zoom Cloud Meeting. Aplikasi ini dilengkapi fitur Sharing Screen yang mampu memfasilitasi kebutuhan pengajar dalam menyajikan bahan ajar layaknya pertemuan tatap muka di dalam kelas konvensional kepada para peserta didik. Peneliti menganggap bahwa Zoom Meeting memang sangat bagus dijadikan sebagai media pembelajaran daring. Gambar 2 adalah contoh fitur sharing screen.

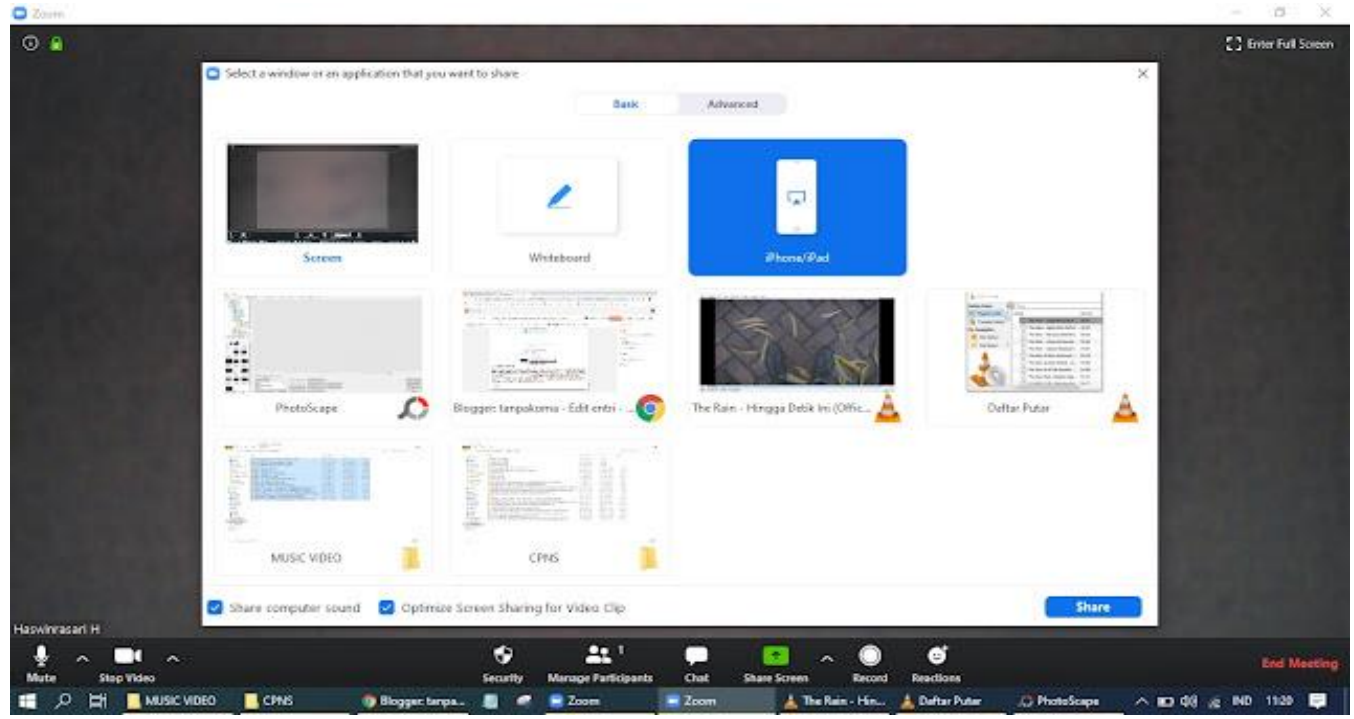

Gambar 2. Tampilan Sharing Screen 
Namun disisi peserta didik, peneliti menemukan tanggapan yang berbeda. Setelah dievaluasi, mayoritas peserta didik SMK Negeri 1 Tanjung Palas menganggap bahwa pembelajaran melalui Zoom cloud Meeting sangat menguras kuota pulsa mereka. Karena memang latar belakang peserta didik memiliki kondisi ekonomi yang menengah kebawah, walaupun peserta didik sudah mendapat bantuan kuota dari pemerintah, namun terkadang tidak cukup.Untuk itu, maka kendala yang terkait langsung dengan nilai ekonomi harus disiasati secara bijak, agar proses belajar secara daring dapat berlangsung secara adil. Selain soal kuota yang dirasa memberatkan, pembelajaran daring melalui Zoom Meeting terkadang menurut sebagian mereka terkendala dengan signal yang tidak stabil, sehingga Zoom meeting yang mereka akses kadang terputus-putus. Faktor ini diakibatkan jangkauan lokasi setiap provider yang peserta didik gunakan, dengan lokasi tempat mereka mengakses Zoom meeting berbedabeda sehingga hal tersebut dapat terjadi. Untuk faktor ini bisa dianggap sebagai aspek yang paling penting , karena jika pembelajaran melalui Zoom meeting tetap dipaksakan, maka tidak semua peserta didik dapat merasakan manfaat dari materi yang disampaikan, karena sebagian dari mereka masih terkendala dengan kondisi signal yang buruk. Walaupun sebagian ada juga yang senang dengan pembelajaran melalui zoom dikarenakan memiliki fasilitas internet berlangganan yang lebih stabil signalnya. Gambar 3 adalah contoh penggunaan zoom meeting dalam pembelajaran daring.

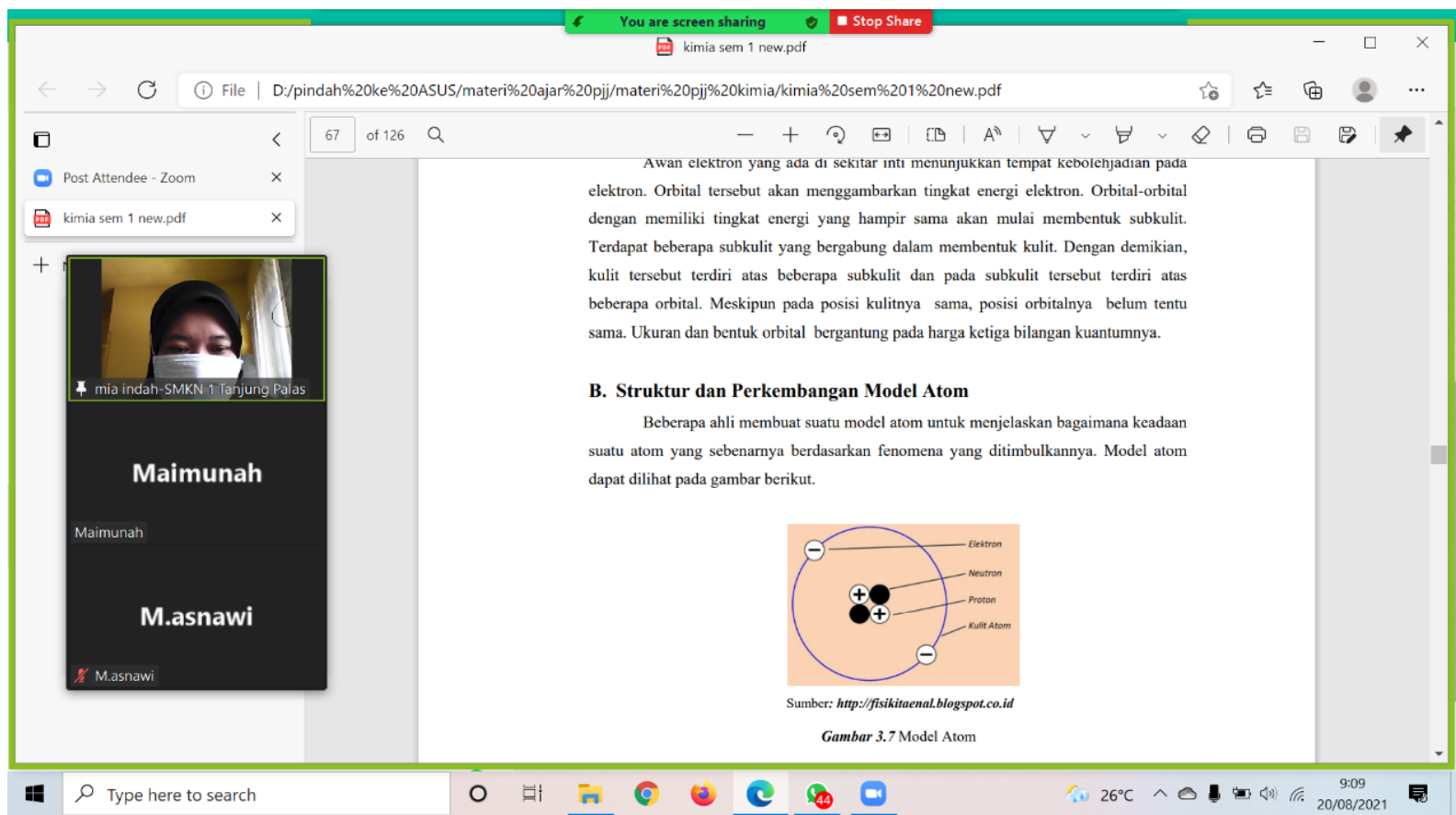

Gambar 3. Tampilan Zoom Meeting pada kelas X APHPI pembelajaran kimia

\section{Evaluasi}

Salah satu cara untuk meningkatkan kualitas pembelajaran adalah dengan evaluasi. Penilaian menggunakan metode pembelajaran google classroom dan Zoom Cloud Meeting dilakukan beberapa kali tahapan. Adapun yang dievaluasi adalah aspek kognitif (pengetahuan), keterampilan, dan karakter siswa dengan melihat hasil dari penerapan kedua metode yang disebutkan sebelumnya. Penilaian pengetahuan didasarkan pada hasil kerja siswa yakni tanya jawab secara langsung melalui zoom meet dalam proses pembelajaran berlangsung serta jawaban siswa pada LKPD. Tanya jawab secara langsung selain sebagai penilaian juga dapat digunakan sebagai bentuk interaksi antara guru dan siswa, dengan begitu guru dapat mengetahui materi apa saja yang belum dikuasai dan dipahami oleh siswa. Penggunaan zoom meet ini akan mendorong peningkatan keaktifan siswa dalam pembelajaran daring. Penilaian karakter (sikap) khususnya tepat waktu atau kedisiplinan dalam penelitian ini diperoleh dari 
ketepatan waktu siswa dalam menyerahkan tugas pada google classroom. Dengan menggunakan google classroom maka siswa akan mengetahui deadline tugas mereka. Selain itu siswa akan terhindar dari keterlambatan pengumpulan tugas ketika guru mengaktifkan pemberitahuan deadline tugas pada siswa dengan menggunakan google calendar. Hal tersebut memiliki kesamaan dengan penelitian Pradana (2017) dimana proses pembelajaran yang menggunakan Google Classroom akan lebih menarik dan lebih praktis dalam hal manajemen waktu, sebab tidak ada alasan lagi bagi siswa untuk lupa mengumpulkan tugas yang sudah diberikan oleh guru.

Hasil di lapangan pada saat siswa mengerjakan LKPD, nilai siswa sebelum dan sesudah menggunakan media Google Classroom dan Zoom Meeting dalam pembelajaran Kimia materi struktur atom kelas X APHPI SMK Negeri 1 Tanjung Palas dapat dilihat pada tabel berikut ini:

Tabel 1. nilai prestasi belajar siswa sebelum menggunakan Google classroom dan zoom meeting

\begin{tabular}{|c|l|l|l|}
\hline NO & \multicolumn{1}{|c|}{ NAMA } & Nilai & \multicolumn{1}{c|}{ Keterangan } \\
\hline 1 & Achmad Syahrullah & 50 & Tidak Tuntas \\
\hline 2 & Grensen & 50 & Tidak Tuntas \\
\hline 3 & Henok Laden & 45 & Tidak Tuntas \\
\hline 4 & Hidayat & 45 & Tidak Tuntas \\
\hline 5 & Hizril & 50 & Tidak Tuntas \\
\hline 6 & $\begin{array}{l}\text { Iman Handika } \\
\text { Supriansyah }\end{array}$ & 40 & Tidak Tuntas \\
\hline 7 & Indiani & 60 & Tidak Tuntas \\
\hline 8 & M. Asnawi & 65 & Tidak Tuntas \\
\hline 9 & M. Wahyudi & 70 & Tuntas \\
\hline 10 & Maimunah & 80 & Tuntas \\
\hline 11 & Mutia & 80 & Tuntas \\
\hline 12 & Nur Jamilah & 60 & Tidak Tuntas \\
\hline 13 & Patimah & 70 & Tuntas \\
\hline 14 & Ronaldus Retno & 65 & Tidak Tuntas \\
\hline 15 & Rustam & 60 & Tidak Tuntas \\
\hline 16 & Siti Anisa Fadilah & 65 & Tidak Tuntas \\
\hline 17 & Tina Juliani & 60 & Tidak Tuntas \\
\hline 18 & Ulfa Yuana & 75 & Tuntas \\
\hline 19 & Vini Sakira Imelda & 70 & Tuntas \\
& Fahmi & & \\
\hline
\end{tabular}

Tabel 2. nilai prestasi belajar siswa setelah menggunakan Google classroom dan zoom meeting

\begin{tabular}{|c|l|l|l|}
\hline NO & \multicolumn{1}{|c|}{ NAMA } & Nilai & \multicolumn{1}{c|}{ Keterangan } \\
\hline 1 & Achmad Syahrullah & 75 & Tuntas \\
\hline 2 & Grensen & 70 & Tuntas \\
\hline 3 & Henok Laden & 70 & Tuntas \\
\hline 4 & Hidayat & 75 & Tuntas \\
\hline 5 & Hizril & 75 & Tuntas \\
\hline 6 & $\begin{array}{l}\text { Iman Handika } \\
\text { Supriansyah }\end{array}$ & 80 & Tuntas \\
\hline 7 & Indiani & 80 & Tuntas \\
\hline 8 & M. Asnawi & 75 & Tuntas \\
\hline
\end{tabular}




\begin{tabular}{|c|l|l|l|}
9 & M. Wahyudi & 75 & Tuntas \\
\hline 10 & Maimunah & 80 & Tuntas \\
\hline 11 & Mutia & 85 & Tuntas \\
\hline 12 & Nur Jamilah & 65 & Tidak Tuntas \\
\hline 13 & Patimah & 75 & Tuntas \\
\hline 14 & Ronaldus Retno & 65 & Tidak Tuntas \\
\hline 15 & Rustam & 75 & Tuntas \\
\hline 16 & Siti Anisa Fadilah & 75 & Tuntas \\
\hline 17 & Tina Juliani & 80 & Tuntas \\
\hline 18 & Ulfa Yuana & 80 & Tuntas \\
\hline 19 & $\begin{array}{l}\text { Vini Sakira Imelda } \\
\text { Fahmi }\end{array}$ & 85 & Tuntas \\
\hline
\end{tabular}

Dari hasil penelitian, terjadi peningkatan dalam ketuntasan belajar siswa X ATPH pada materi struktur atom.

Tabel 3. Hasil pembelajaran kimia

\begin{tabular}{|l|l|c|c|c|c|}
\hline \multirow{2}{*}{$\begin{array}{c}\text { Sebelum Menggunakan } \\
\text { Google Classrom dan } \\
\text { Zoom Meeting }\end{array}$} & \multicolumn{2}{|c|}{ Hasil } & Setelah Menggunakan & \multicolumn{2}{c|}{ Hasil } \\
\cline { 5 - 6 } \cline { 5 - 6 } & Jumlah & Presentase & $\begin{array}{c}\text { Google Classrom dan } \\
\text { Zoom Meeting }\end{array}$ & Jumlah & Presentase \\
\hline Tuntas & 6 siswa & $31,58 \%$ & Tuntas & 17 siswa & $89,47 \%$ \\
\hline Tidak Tuntas & 13 siswa & $68,42 \%$ & Tidak Tuntas & 2 siswa & $10,53 \%$ \\
\hline Jumlah Obyek & 19 siswa & & Jumlah Obyek & 19 siswa & \\
\hline
\end{tabular}

\section{PEMBAHASAN}

Pemanfaatan Google Classroom dan Zoom meeting cukup efektif dalam pembelajaran Kimia di SMK Negeri 1 Tanjung Palas, terlihat dari ketuntasan belajar siswa dalam pembelajaran Kimia materi struktur atom. Sebelum menggunakan kedua platform tersebut sangat rendah. Yang tuntas hanya 31,58\% persen (6 orang) dari 19 siswa kelas X ATPH yang menjadi obyek penelitian, dan yang tidak tuntas mencapai $68,42 \%$ persen (13 orang). Setelah memanfaatkan / menggunakan kedua media tersebut, maka terjadi perubahan yang signifikan, yaitu; Siswa yang tuntas mencapai $89,47 \%$ persen atau 17 orang, dan yang tidak tuntas hanya $10,53 \%$ atau 2 orang. Solusi atau saran untuk $10,53 \%$ persen ( 2 orang) yang tidak tuntas karena faktor jaringan internet kurang maksimal di rumah tempat tinggalnya, dan fasilitas komputer, Laptop atau HP yang dimiliki kurang memadai, dapat bergabung dengan temannya memiliki fasilitas memadai dan jaringan internet yang maksimal

\section{KESIMPULAN}

Dengan penggunaan google classroom dan zoom cloud meeting ini, mempermudah para guru maupun siswa dalam kegiatan proses pembelajaran daring. Mengintegrasikan kedua media tersebut dapat memberikan pendidikan karakter disiplin, keaktifan, pencapaian kreativitas, melek informasi, berkolaborasi dan tanggung jawab. Karakter disiplin siswa dapat dicapai karena aplikasi google classroom menyediakan setting waktu pengerjaan dan pengumpulan tugas. Guru dapat mengatur waktu pengumpulan tugas secara mudah.Kemudian ketuntasan belajar siswa pun meningkat setelah menggunakan Google classroom dan zoom meeting.

\section{DAFTAR PUSTAKA}

Al-Maroof, R.S., et al. (2020). Fear from COVID-19 and technology adoption: the impact of GoogleMeet during Coronavirus pandemic. Interactive Learning Environments, 1-16.

Aryani, D., Malabay, M., Ariessanti, H. D., \& Putra, S. D. (2020). Pelatihan Pemanfaatan Google Classroom untuk Mendukung Kegiatan Pembelajaran Daring saat Pandemi COVID-19 di SMPIT Insan Rabbani, Jurnal Abdidas, 1(5), 373-378. 
Beal, V. (2020). Google Classroom. Editor of webopedia

Brahma, I. A. 2020. Penggunaan Zoom Sebagai Pembelajaran Berbasis Online Dalam Mata Kuliah Sosiologi dan Antropologi Pada Mahasiswa PPKN di STKIP Kusumanegara Jakarta. Aksara: Jurnal Ilmu Pendidikan Nonformal, 6(2), 97.

Efendi, S \& Marpaung, R. F. (2018). Implementasi Mobile Learning Dengan Model Advance Organizer Dalam Meningkatkan Kemampuan Kognitif Kimia Mahasiswa. PeTeKa Jurnal Penelitian Tindakan Kelas dan Pengembangan Pembelajaran, 1(3): 171-178.

Hakim, A. B. (2016). Efektivitas Penggunaan E-Learning Moodle, Google Classroom Dan Edmodo. ISTATEMENT, 2: 1-6.

Kusuma Dewi, Tuisda Pratisia, Alfyananda Kurnia Putra.(2021). Implementasi Pemanfaatan Google Classroom, Google meet, dan Instagram Dalam Proses Pembelajaran Online Menuju Abad 21. Jurnal Integrasi dan Harmoni Inovatif Ilmu-Ilmu Sosial, 1(5), 2021, 533-541.

Liu, H. C., \& Chuang, H. H. (2016). Integrating Google Classroom to Teach Writing in Taiwan. Minnesota eLearning Summit.

Mahayoni, N. M. S. (2020). Penggunaan Aplikasi Zoom Meeting Pada Pembelajaran Agama Hindu Di Masa Pandemi. Jurnal Widya Sastra Pendidikan Agama Hindu, 3(1), 47-53

Naserly, M. K. (2020). Implementasi Zoom, Google Classroom, Dan Whatsapp Group Dalam

Mendukung Pembelajaran Daring (Online) Pada Mata Kuliah Bahasa Inggris Lanjut. EDUTECH CONSULTANT BANDUNG Jurnal AKSARA PUBLIC, 4(2): 155-165.

Okmawati, M. (2020). The Use of Google Classroom During Pandemic. Journal of English Language Teaching, 9(2): 439-443.

Pradana, D. B. P.(2017). Pengaruh Penerapan Tools Google Classroom Pada Model Pembelajaran Project Based Learning Terhadap Hasil Belajar Siswa. IT-Edu: Jurnal Information Technology and Education, 2(1).

Wicaksono, M. D. (2020). Pemanfaatan Google Classroom dalam Strategi Pembelajaran Kooperatif pada Mata Pelajaran IPS Kelas VIII. Inspirasi (Jurnal Ilmu-Ilmu Sosial), $17(1)$. 